\title{
Lumen
}

Selected Proceedings from the Canadian Society for Eighteenth-Century Studies

\section{Radical Customs: Maréchal's Critique of Religion and Politics in Serial Works on Distant Civilizations}

\section{Erica J. Mannucci}

Volume 36, 2017

URI : https://id.erudit.org/iderudit/1037860ar

DOI : https://doi.org/10.7202/1037860ar

Aller au sommaire du numéro

Éditeur(s)

Canadian Society for Eighteenth-Century Studies / Société canadienne d'étude du dix-huitième siècle

ISSN

1209-3696 (imprimé)

1927-8284 (numérique)

Découvrir la revue

Citer cet article

Mannucci, E. J. (2017). Radical Customs: Maréchal's Critique of Religion and

Politics in Serial Works on Distant Civilizations. Lumen, 36, 161-176.

https://doi.org/10.7202/1037860ar 


\title{
Radical Customs: Maréchal's Critique of Religion and Politics in Serial Works on Distant Civilizations
}

\author{
ERica J. Mannucci \\ University of Milano-Bicocca
}

In French intellectual and cultural history, the 1780 s are a liminal period in which the plural cultures of the Revolution were formed in many of their basic elements before their exponents knew they would, or could, actually be revolutionary. ${ }^{1}$ Much attention has rightly been paid by historians to the role of clandestine and unauthorized publications and their circulation in the origins of revolutionary attitudes. ${ }^{2} \mathrm{We}$ will focus here instead on a particular author's veiled uses of commercial and authorized media to convey anti-religious and politically radical contents.

If we now tend to see that story as a linear progression - even though we still discuss the concurrent causes of the event - it should not be considered unimportant that the protagonists may have had

1. The plurality of revolutionary cultures has been recently stressed and redefined by Jonathan Israel, "Conclusion - The Revolution as the Outcome of the Radical Enlightenment," in Revolutionary Ideas. An Intellectual History of the French Revolution from The Rights of Man to Robespierre (Oxford-Princeton: Princeton University Press, 2014), 695-708, the latest part of his monumental history of European Radical Enlightenment. My perspective on that plurality, however, should not be taken as coinciding with his.

2. Classic references include Robert Darnton, The Literary Underground of the Old Regime (Cambridge, MA-London: Cambridge University Press, 1982) and The Forbidden Best-Sellers of Pre-Revolutionary France (London: HarperCollins, 1996); Daniel Roche, Les Républicains des lettres. Gens de culture et lumières au XVIII e siècle (Paris: Fayard, 1988); Roger Chartier, The Cultural Origins of the French Revolution (Durham, NC: Duke University Press, 1991). 
different time perceptions. Sylvain Maréchal - one of the future leaders of Gracchus Babeuf's Conspiracy of Equals - seemed almost ready to give up the fight at the age of 37 , in 1788 , mere months before the first premonitory signs of a radically changing political climate appeared. In January the Parisian poet was arrested for his anti-religious Almanach des honnêtes gens: this episode would later become his revolutionary credential as a martyr of free thought and make the publication itself a best-seller. ${ }^{3}$ However, at the time it happened, being jailed at Saint-Lazare - the prison for immoral people and rebel sons - shocked and shamed this man who had raised himself from lower class origins through education and prized his self-image of personal virtue and dignity. ${ }^{4}$

His three months in jail conditioned his attitude even into the revolutionary years. ${ }^{5}$ After his release in mid-April, Maréchal prudently went back to clandestine publishing or anonymity for his openly political and anti-religious writings. ${ }^{6}$ On the other hand, he was still quite visible as the author of commercial serial works on less obvious subjects which still allowed scope for the dissemination of some of his ideas.

\section{Writing on Commission}

Maréchal's work offers an interesting case-study relevant to the broader subject of the state of the book in the late 18th century. From 1770 to

3. See his unsigned article, "Du nouveau calendrier," Révolutions de Paris, 212 (August 3-October 28, 1793), 108. For a contemporary testimony on the success of his Almanach, Jean- Pierre Beyerlé, "Notice sur les Calendriers, les Almanachs et sur le but de l'Almanach des femmes célèbres," in Almanach des femmes célèbres pour l'an VI de la République française (Paris: Beyerlé, 1797), IX-XV. On all aspects of the perception of time in the revolutionary period and on Maréchal's calendar, see Sanja Perovic, The Calendar in Revolutionary France. Perceptions of Time in Literature, Culture, Politics (New York: Cambridge University Press, 2012).

4. See his letter from the prison to his fiancée Mlle Després and her sister, Russian State Archives for Political and Social History (RGASPI), Fond 471, opis 2, 42, 1,1 overleaf, 2 and on this side of his character, [Marie-Armande Gacon-Dufour], "Notice sur Sylvain Maréchal," in Sylvain Maréchal, De la vertu (Paris: Léopold Collin, 1807), 36 .

5. See his reaction to trouble with the police created in 1790 by his Catéchisme du curé Meslier, published in his own newspaper Tonneau de Diogène, in an undated letter to Annette Duplessis, RGaspi, 471, 2, 40.

6. Starting with his unsigned Apologues modernes à l'usage du Dauphin, printed clandestinely in two editions in 1788 and early 1789. 
1802, his writing career - not unlike those of other professional writers in his generation - not only spans all types of genres and self-representations, but of publishing forms as well: from clandestine to commercial, from erudite to propagandistic. The focus here will be on one form and period: multi-volume commercial works of the 178 os on the culturally revealing and connected subjects of peoples distant in space or time. These publications responded to the strong demand of the time for instructive reading including sets of good-quality illustrations and curiosities stimulated in the reading public by travel narratives and various aesthetic and cultural fashions.

Maréchal began writing on commission at the beginning of the 1780 , drawing on his vast and partly self-taught learning, especially on the classical world. This became his only way to support himself when, in 1784 , he was fired by the Bibliothèque Mazarine, where he was an assistant librarian. He was removed because of the radical political and social critique in his Livre échappé au deluge and the fact that he had dared circulate it from the library itself. The Mazarine, as the clergymen who directed it knew, was a meeting place for a few unconventional thinkers and their young admirers. ${ }^{7}$ It was there that Maréchal had met the men who were his own "professors of atheism," as the abbé Mulot called one of them, the economist Fréville, who liked to advocate his ideas in public. ${ }^{8}$

Maréchal's life became very difficult. Even before that time, however, he had needed to go against his opinions, as when he had acted as ghostwriter for an ambitious but shady client like Hennique de Chevilly, who commissioned parts of a Dictionnaire ecclésiastique and then did not pay him. ${ }^{9}$ Ambiguous figures like this patron were the "literary speculators" Maréchal referred to in 1788 in a text on Parisian life:

7. Regarding Maréchal's relations with young readers seeking his advice, see Gacon-Dufour, "Notice." Maréchal wrote about the people he met at the Mazarine to his friend Jacques Lablée. These papers are partly in the collection of the Institut français d'histoire sociale, Fonds Dommanget 14 AS 287 and partly in RGASPI, 471, 2; later he remembered them in his Dictionnaire des athées anciens et modernes (Paris: Grabit, 1800).

8. François-Valentin Mulot, Journal intime de l'abbé Mulot, ed. Maurice Tourneux (Paris: Daupeley-Gouverneur, 1902), 77-79.

9. See Jacques-Pierre Brissot de Warville, Mémoires (1754-87), ed. Claude Perroud (Paris: Alphonse Picard, n.d.), I, 175-76. 
Contractors of printed works who hire brains and get fat in guilty leisure on the sweat of ignored talent working without pause in their offices. Paris is teeming with these literary speculators, these swindlers of Wit, who manufacture books - unable to write anything, but charlatans in selling; they are the worthy rivals of the Booksellers, who do not see them kindly $[\ldots]^{10}$

Clearly, he put the professional booksellers in a different category, though the last sentence of this quotation suggests that he resented some of them almost as much as the charlatan speculators: in professional publishing projects, he usually was at least a recognized author rather than a ghostwriter. They could nonetheless be an equally uncertain form of employment. This was the case with Paris et la Province, an illustrated description of architectural monuments launched in 1786 by engraver André Le Campion, who advertised a wide circulation in France and abroad, but interrupted the project - as far as we know after two instalments. ${ }^{11}$

Two important works - both approved by the king's censor and printed with a privilège - Maréchal wrote and got credit for were the Antiquités d'Herculanum, an endeavor begun in 1780 and finished with vol. XII in 1803 (Maréchal's last, vol. XI, came out in 1798); and the Costumes civils actuels de tous les peuples connus, four volumes published in 1788. The narrative of the second (organized into chapters with separate pagination), started with an account of Parisian life and costumes and moved seamlessly from nation to nation, from Europe to Asia - connected through the succession of Russian peoples found traveling eastward - and the other continents.

\section{Uses of Antiquity}

Parisian engraver and publisher François-Anne David's Antiquités d'Herculanum was the more mainstream enterprise. It was presented

10. Sylvain Maréchal, Costumes civils de tous les peuples connus, 4 vols. ( Paris: Pavard, 1788), vol. I, 8 (all translations are mine).

11. [Sylvain Maréchal], Paris et la province, ou choix des plus beaux monumens d'architecture, anciens et modernes, Dessiné par Testard, gravé en couleur par J.A. Le Campion (Paris: Le Campion, 1786). Maréchal's name did not appear on the title page of the first instalment, while he figured as the author of the second. The Bibliothèque Nationale in Paris only has the first instalment, on the Cité (4-L2O-10) - see the cities where it was circulated on back cover. 
as an ongoing translation of the report on the archeological finds in the Ancient Roman town given, from 1757 to 1792, by the Herculaneum Academy, founded by the king of Naples in 1755. These spectacular discoveries (followed by those of Pompeii and later Paestum) were an important event in European cultural history, particularly because they offered a wealth of new data on which to base judgments on the pictorial art of the Ancients - until then, available vestiges had been very limited. These finds both renewed the Quarrel of the Ancients and Moderns and put the South on the map of cultured visitors to Italy, beginning with Président de Brosses. ${ }^{12}$ Equally well-known are Johann Winckelmann's reports on those finds at the beginning of the $1760{ }^{13}$

When the Antiquités enterprise began, the news about Herculaneum had already influenced taste (more than art itself) in various parts of Europe, creating a fashion in furniture, jewels and decorative sculpture. It has been noted, however, that French society had been slower than others in adopting this fashion: Chantal Grell and Christian Michel tend to see the first volumes of the Antiquités d'Herculanum as promoting as much as amplifying the trend. ${ }^{14}$ The volumes were richly illustrated with very precise engravings, where the imperfections in the originals (mistakes in the perspective, for example) were usually

12. On the inestimable documental value of the frescoes found in Herculaneum, see Charles de Brosses's Lettres d'Italie - L'Italie il y a cent ans, ou Lettres écrites d'Italie par Charles de Brosses, ed. Romain Colomb, (Paris: Alphonse Levavasseur, 1836), "Lettre XXXIII à M. le Président Bouhier, Mémoire sur la ville souterraine d'Ercolano," (28 novembre 1739), 411-25. On the Querelle see Larry F. Norman, The Shock of the Ancient. Literature and History in Early Modern France (Chicago: The University of Chicago Press, 2011); on travelers to Southern Italy and their reports, Emanuele Kanceff and Roberta Rampone, eds., Viaggio nel Sud, 3 vols. (MoncalieriGenève: C.I.R.V.I.-Slatkine, 1992).

13. See Victoria C. Gardner Coates and Jon L. Seydl, eds., Antiquity Recovered: the Legacy of Pompeii and Herculaneum (Los Angeles: J. Paul Getty Museum, 2007); and Eric M. Moorman, Pompeii's Ashes. The Reception of the Cities Buried by Vesuvius in Literature, Music and Drama (Boston-Berlin-Munich: Walter de Gruyter, 2015). See a fine detailed analysis of the wider implications of responses to Winckelmann's ideas on ancient art in France in Edouard Pommier, "Winckelmann et la vision de l'Antiquité classique dans la France des Lumières et de la Révolution," Revue de l'Art, 83 (1989), 9-20.

14. Chantal Grell and Christian Michel, "Érudits, hommes de lettres et artistes en France au XVIII siècle face aux découvertes d'Herculanum," in Luisa Franchi Dell'Orto, ed., Ercolano, 1738-1988: 250 anni di ricerca archeologica, Atti del convegno internazionale (Roma: L'Erma di Bretschneider,1993),133-44: 142. 
corrected: a common practice at the time, meant to both show respect toward the Ancients and prove the engraver's artistic skills. ${ }^{15}$

Maréchal's text, however, was much more than a description of the printed images or a translation. Its philosophical contents are all the more interesting because the author was to be a prominent intellectual of the French Revolution. His ideas on the Egyptians, the Greeks and the Romans can thus represent the less obvious uses of Antiquity in the formation of revolutionary culture.

Maréchal, who did admire some aspects of Rousseau's intellectual and moral model, when it came to the Ancients was closer to the preferences Diderot expressed in his Encyclopédie article on the philosophy of Romans, a text which was reprinted during the Revolution by his philosophical heir Jacques-André Naigeon in his Philosophie ancienne et moderne, part of the Encyclopédie méthodique. Cato, a figure Rousseau glorified as an example of rigorous patriotic virtue, was despised by Diderot for his attempt to ban Greek philosophy in Rome. "It is far easier to drive off philosophers than to become one," wrote Diderot of the republican Romans; and among the Ancients Maréchal certainly identified not with harsh patriots, but with sages and philosophers, particularly those who, at least since Cicero, were remembered as atheists. ${ }^{16}$

Thus, the choice of another image of Antiquity in a revolutionary intellectual like Maréchal can suggest a questioning of the cliché of the Rousseauian French Republican. It can qualify, in other words, the position which reduces all radical revolutionary culture to a stereotyped Jacobinism, seemingly bent on the revival of the harsh patriotic virtue of Sparta and early Republican Rome - bent, that is, on culturally grounding the swallowing up of the individual by the belligerent machine of the common good. ${ }^{17}$

15. See Edith Flamarion, Catherine Volpilhac-Auger, Introduction to MM. Cochin les fils et Bellicard, Observations sur les antiquités de la ville d'Herculanum (Saint-Étienne: Publications de l'Université de Saint-Étienne, 1996), 7-22: 22.

16. Denis Diderot, "Romains, philosophie des Étrusques et des Romains," Encyclopédie, ou Dictionnaire raisonné des sciences, des arts et des métiers (Paris: Briasson, David, Le Breton, 1751-65), XIV, 338-40. Naigeon: see below, note 43.

17. This way of using ancient republican models, amounting to an ideological mania, was famously characterized and denounced by Volney in Year III (1795), in his Leçons d'Histoire at the newly founded École Normale. For early doubts on this cliché, see Elizabeth Rawson, The Spartan Tradition in European Thought (Oxford: 
Maréchal, on the contrary, considered Lycurgus a negative example of the methods of power, seen, in his atheistic perspective, as cynical imposture based on religious lies: we can see this idea quite clearly in a late 178 os manuscript on the history of ancient Greece, now at the Société Éduenne in Autun. ${ }^{18}$ We can recognize this strand of revolutionary culture in other writers of Maréchal's generation, those who would later reappear in groups such as the Portique républicain - a literary society formed a month before Bonaparte's coup by revolutionary writers like Evariste Parny or Charles Pigault-Lebrun, who wanted to defend the radical secular heritage of the closing 18th century against the Catholic revival. ${ }^{19}$ This strand largely came from the intellectual tradition of atheism or radical critique of religion. It implied a whole vision of reality, past, present and future and perhaps a few anti-authoritarian anti-bodies. ${ }^{20}$

Maréchal's version of the origins of inequality was more Lucretian than Rousseauian in its stress on the will to dominate as the pre-condition of private property and on the calamitous human and social consequences of religion. ${ }^{21}$ Thus, the original scandal for Maréchal

Clarendon Press, 1969) and Luciano Guerci, Libertà degli antichi e libertà dei moderni. Sparta, Atene e $i$ "philosophes» nella Francia del Settecento (Napoli: Guida, 1979), who treats Diderot on the myth of Sparta as well, 99-100. For a recent perspective on Spartan imagery, see Stephen Hodkinson and Ian MacGregor Morris, eds., Sparta in Modern Thought: Politics, History and Culture (Swansea: The Classical Press of Wales, 2012).

18. Maréchal's drafts of chapters on ancient Greece, under the title Histoire de l'antique Grèce, are at the Société Éduenne, Fonds Amaury Duval, K8-32. They are different from the text of the Histoire de la Grèce, published only partially in Paris in 1788 and some parts (on the Athenians) may have been written in a later period.

19. On the Portique see Jean-Luc Chappey, "Le Portique républicain et les enjeux de la mobilisation des arts autour du brumaire an VIII" in Philippe Bourdin and Gérard Loubinoux, eds., Les arts de la scène et la Révolution française (ClermontFerrand: Presses Universitares Blaise-Pascal, 2004), 487-507.

20. See Erica J. Mannucci, "Opposizioni al Concordato: l'ultima fiammata del secolo dei lumi?" in Antonino De Francesco, ed., Da Brumaio ai Cento giorni. Cultura di governo e dissenso politico nell'Europa di Bonaparte (Milano: Guerini, 2007), $157-76$.

21. The Latin materialist poet Lucretius, author of the famous De rerum natura, was one of Maréchal's icons. For a thought-provoking analysis of the notions of property and domination in Rousseau and of their sources and references, see Giuliano Gliozzi, "Rousseau: dalla proprietà al dominio," in Differenze e uguaglianza nella cultura europea moderna, ed. by Anna Strumia (Napoli: Vivarium, 1993), 41259 . 
was not property itself, but the pious lie - the use of religion to justify power and thus an irreversible domination of man over man. In 1781, in his Fragmens d'un poëme moral sur Dieu, he represented with a theatrical image that fatal turn in human history: "Rebels! Be quiet! (an impostor shouts at them) / Tremble! There is a God; of kings he is the avenger: /.. / He is the maker of kings; back into line!."22 Much later, he explained his version of the alliance between the throne and the altar, traditionally denounced by freethinkers:

It is asked whether religion is in the State or the State in religion. It is asked if monarchic government preceded religious government, or not? To me, these two bad products of the human brain are from the same period and source $[. .$.$] When men got priests, they did not remain long$ without masters and vice versa. ${ }^{23}$

Maréchal was deeply pessimistic about power and government and that is why he could not be a reformer; but he also felt out of place and disappointed on many occasions during the Revolution, though he still actively saw himself as part of it. ${ }^{24}$ Not only was he, culturally, a partisan of the Ancients - "in a word, the Greeks are our masters in everything," he wrote in the above mentioned manuscript - but he maintained at all times an idea of happiness which was tied to the ancient ethical image of the Sage. His very vision of fulfillment, in other words, was really closer to the Hellenistic moral philosophies of Life according to Nature - to an ideal of individual autonomy focused on the exercise of private virtues - than to a social concept of happiness such as those prevailing in modernity. "The sage enjoys himself...he is his own universe if the universe abandons him," he wrote in 1779; "Private virtues are the only real virtues" he wrote, in a more explicitly political sense, in $1793 .{ }^{25}$ This attitude helped him to survive psychologically and go on engaging in political battles after the debacle of the

22. [Sylvain Maréchal], Ad majorem gloriam virtutis. Fragmens d'un poëme moral sur Dieu, A Athéopolis, L’An Premier de la Raison (n.p. [prob. Neuchâtel]: 1781), 20.

23. [Sylvain Maréchal], Pensées libres sur les prêtres, à Rome, et se trouve à Paris (n.p.: an VI- 1798), 21.

24. See his political and utopian criticism in Dame Nature à la barre de l'Assemblée nationale, (n.p. [Paris]: 1791), Correctif à la révolution (Paris: Cercle social, 1793) and Correctif à la gloire de Bonaparte, ou lettre à ce général (Paris: Lenfant, Frimaire an VI- November 1797).

25. Sylvain Maréchal, Le Livre de tous les âges ou le Pibrac moderne, à Cosmopolis (Paris: Cailleau, 1779), 14; Maréchal, Correctif à la révolution, XXIV, 21. 
Conspiracy of Equals. ${ }^{26}$ In this clandestine revolutionary plot, he had let himself be seduced as an activist by what he refused as a thinker the idea that happiness could be built on political power.

The manuscript on ancient Greece may have been partly a draft of the commercial Histoire de la Grèce: in the printed version, he opted for a more conventional image of Lycurgus, providing the public just what it expected. ${ }^{27}$ While a manuscript may reveal to intellectual historians a significant aspect of Maréchal's authentic thought, what he wrote in publications for a large readership is more relevant to the cultural and social issue of the circulation and penetration of ideas which would be subject to censorship and repression if proposed in more direct forms. A few quotations from different volumes of the Antiquités d'Herculanum may demonstrate how Maréchal could slip his radical ideas into a commercial and fully authorized work. The same ideas would explode in his comments in the volumes published during the Revolution, volume IX in particular. However the focus here will remain on the pre-revolutionary ones.

Any illustration of ancient paintings, sculptures and other archeological finds could offer a pretext or some leeway for synthetic philosophical allusions and indeed an opportunity for an alternative visual pedagogy. For example, the image of an Egyptian votive hand in the volume on bronze and marble objects: a detailed study, Maréchal wrote, could link the object to a "religion founded on the nature of bodies...very similar to spinozism...the hand will thus represent Nature as agent on its own account...."28

In fact, he thought that Spinoza had derived his ideas - "son système " - from the Ancients, from the figure of Pan as the deification of the Universe, and he significantly cited in a note John Toland's clandestine Pantheisticon as the source of his interpretation. ${ }^{29}$ In his texts he often insisted on this philosophique character of ancient

26. His involvement was not discovered in 1796 and was revealed only later, in 1828 , by another leader, Philippe Buonarroti, in his Conspiration pour l'égalité, dite de Babeuf, 2 vols, ed. by Georges Lefebvre (Paris: Éditions sociales, 1957).

27. See above, note 18 .

28. Antiquités d'Herculanum, gravées par F.A. David avec leurs explications par P. S. Maréchal, 12 vols., (Paris: F.A. David, 1780-1803), vol. VI, 12. It is not easy to date each volume: this certainly came out after 1783 , the date of Erotika Biblion by Mirabeau fils, cited in a footnote.

29. Ibid., vol. III, 168. 
mythology. Pan was only one of the images he used in the Antiquités, alongside terms like "Ame du Monde," Nature as "Panthea," the Isiac maxim "Una quae est omnia" ("the one who is all"), which revealed the signs of a historically widespread if not entirely correct reading of Spinoza's Deus sive natura and its projection onto the civilizations of the past. ${ }^{30}$

In another passage he showed that his moralism was not sanctimonious: Pan was "the God of Nature and of Lust, maybe one and the same in the eyes of the Ancients": far from blushing about it, they sanctified the act of generation. ${ }^{31}$ A similar God of the wild, Bacchus, or Dionysus, was the God of Liberty and Patron of republics, but also, "according to the Ancients' theogony, the first to crown kings and consecrate the servitude of peoples." Maybe - Maréchal commented - the ancient peoples wanted to show posterity that only drunken people out of their minds could submit to a king. ${ }^{32}$

Elsewhere, the image of a naked old man provided Maréchal with an opportunity to glorify the Greek Cynics as positive heroes of morality and virtue, choosing to extol Antisthenes and Diogenes because he felt they were atheists, as he was: "They did not write books, but they showed with their whole private lives that morality can have its heroes ...."

Writing in Old Regime France, he had to condemn Diogenes' shameless behavior, even if to him, as refusal of the rules of society - of nomos - it had a deep moral meaning. Thus he wrote of the old Cynics: "If their philosophy was a bit pessimistic, and their habits less than decent, their sublime principles [...] earned them the admiration of their contemporaries and the amazement of posterity." ${ }^{33}$ Proselytes of the Holbachian campaign, as we can consider Maréchal to have been, were still ambivalent about publicizing and democratizing the intellectual tradition of atheism and inclined to toy with double doctrine. ${ }^{34}$

30. For an example of the use of these terms see ibid., vol. V, 76 .

31. Ibid., vol. II, 67 .

32. Ibid., vol. II, 100.

33. Ibid., vol. III, p. 76. On the role of the model of independence of the Cynic sages in the philosophes, see Louisa Shea, The Cynic Enlightenment. Diogenes in the Salon (Baltimore: Johns Hopkins University Press, 2010), who briefly mentions the presence of Diogenes in revolutionary culture. Maréchal would have a role in assuring the presence of this cultural reference.

34. On the problem of double doctrine in Maréchal see Erica J. Mannucci, Finalmente il popolo pensa. Sylvain Maréchal nell'immagine della Rivoluzione fran- 
However, he certainly thought he could add with his writings to the numbers of that specific admiring posterity in his own times. He saw his destiny inscribed in his very name: "The philosophers said that Sylvain was the god of Matter..." he wrote in the Antiquités. ${ }^{35}$

\section{All the Known Peoples...}

The Costumes civils actuels de tous les peuples connus belonged to the commercial genre invented in Holland in the 1720 s by engraver Bernard Picart and author Jean Frederic Bernard with their Cérémonies et coutumes religieuses de tous les peuples du monde (1723-37). In their fine historiographic analysis, L. Hunt, M.C.Jacob, W.Mijnhardt write that this new genre "broke the confines of encyclopedias, dictionaries or collections of engravings." ${ }^{36}$ Its interest lay, furthermore, in an implicitly radical and secularizing aspect which made it a long-term intellectual model, in that it was a comparison of religions on equal terms - a challenge to intolerance. An international success, the Ceremonies were immediately listed in the Pope's Index of Forbidden Books.

In the 1780 os, the same genre catered to widespread curiosity about the latest European contacts with faraway peoples. In the Costumes civils actuels the message was definitely anti-religious, if still in a semicovert way. Peripheral peoples - including insular European groups and nomadic or persecuted groups (like the Waldensians in Piedmont) were considerably over-represented in this global account: they were a

cese (Napoli: Guida, 2012), 74-80 and passim. On the persistence of an elitism issue in the modes of communication of the philosophes, see Franck Salaün, "La question de la double doctrine en France de Deslandes à d'Holbach” in Laurent Jaffro, Benoît Frydman, Emmanuel Cattin, eds., Léo Strauss: art d'écrire, politique, philosophie (Paris: Vrin, 2001), 221-37; also see Miguel Benitez, La face cachée des Lumières. Recherches sur les manuscrits philosophiques clandestins de l'âge classique (ParisOxford: Universitas-Voltaire Foundation, 1996), 199-211; Olivier Bloch, "L'héritage clandestin dans le matérialisme des Lumières," Dix-Huitième siècle 24 (1992), 73-82; Roland Mortier, Clarté et ombres du siècle des Lumières (Genève: Droz, 1969), 60-103 and Le Coeur et la Raison (Oxford-Bruxelles-Paris: Voltaire Foundation, 1990), 213-21, 364-82.

35. Maréchal, Antiquités d'Herculanum, vol. IV, p. 40.

36. Lynn Hunt, Margaret C. Jacob and Wijnand Mijnhardt, The Book That Changed Europe. Picart and Bernard's Religious Ceremonies of the World (Cambridge, MA-London: The Belknap Press of Harvard UP, 2010), 3. See ibid., Appendix B, for a list of the editions in French, English and other languages in the 18th century and the first half of the 19th: 313-16. 
promising subject for this kind of message, because they offered new material to the Baylean topos of the actual existence of societies of atheists. Pierre Bayle himself had examined a strand of utopian literature which was connected to this theme, in the article "Sadeur" of his Dictionnaire. ${ }^{37}$ Gabriel de Foigny's 1676 libertine utopia La Terre australe connue, whose protagonist was called Sadeur, played on the usual ambiguity between imaginary travels in faraway countries and real accounts, and imagined a frugal society of equals, with neither government nor religion.

For Maréchal, the Costumes civils commission offered an opportunity to provide a selective, engaged, reading of the existing materials on travels: not only Cook or Bougainville, but for example Chappe d'Auteroche on Russian populations. Already well developed by the philosophes in their greatest works, Voltaire and Montesquieu heading the list, this oriented reading of travel literature could be readapted at a more popular level to project a powerful if still partially veiled critical and even utopian message. It could count on a strong reality effect, created by planetary empirical evidence and on the effectiveness of a good measure of visual entertainment: in the 1780 s, sheer exoticism and fashion - being able to see the toilettes, the way people dressed in different countries - had come to acquire a sort of mass appeal in themselves. Maréchal would later list as evidence the same populations he interpreted here as pantheistic in his 1790 revolutionary pamphlet on an acceptable form of civil religion, in fact a family cult of Nature - the Décret de l'Assemblée nationale portant règlement d'un culte sans prêtres.

The Costumes civils enterprise had been launched by a successful publishing adventurer born in Montreal, Jacques Grasset de SaintSauveur. ${ }^{38}$ This nobleman was a free-thinker and probably a member of Freemasonry like Maréchal. A traveler and a diplomat, he was a writer himself and an illustrator, with a particular taste for costumes.

37. Pierre Bayle, Dictionnaire historique et critique, Bnfr Gallica database, ed. by Adrien Beuchot (Paris: Desoer, 1820-24), "Sadeur," vol. XIII, 6-14; also see "Spinoza," vol. XIII, 416-68.

38. Grasset has been thoroughly studied by Bernard Andrès, "Jacques Grasset de Saint-Saveur (1757-1810), aventurier du livre et de l'estampe," "Première partie: La lettre de 1785 au comte de Vergennes," Les cahiers des dix, 56 (2002), 193-215 and "Deuxième partie: du costume à la tenue d'Ève," Les cahiers des dix, 57 (2003), $323-52$, and in other articles. 
After the first edition of $1784-87$ in two volumes, Grasset sold his privilege for eight thousand livres to publisher Pavard, who reprinted the work in four volumes and apparently sold it again in the same year 1788 to another bookseller, Deterville, who had just started his own printing enterprise. This second publisher immediately produced another edition with fewer illustrations. ${ }^{39}$ The text always remained Maréchal's (he revised it for this final 1788 edition). Jean-François Deterville, who would immediately rally to the Revolution and have a successful career, would also be the publisher of Maréchal's Voyages de Pythagore in Year VII (early 1799). Grasset's collaboration with likeminded Maréchal lasted for a few years as well, notably with another enterprise on ancient mythology, the Tableaux de la Fable, nine volumes from 1785 to 1787 .

On some of the peoples Maréchal interpreted in his distinctive way a whole literature already existed, to which the revolutionary period would only add: this is the case of the Ghebres, the followers of Zoroaster in Modern Islamic Persia. ${ }^{40}$ The image of this population had served critical purposes at least since Gabriel Naudés Apologie pour les grands hommes soupçonnés de magie - that is, even before Thomas Hyde's Historia religionis veterum Persarum (1700) and the complete account of Jean Chardin's Voyages en Perse (1711) appeared - and then recurrently during the Enlightenment: "The most emblematic of all the figures of identification and projection, running through the whole [Eighteenth] century, from Montesquieu to Voltaire, is undoubtedly that of the Ghebres, the ancient Persian adorers of the Sun who became a minority in their own country conquered by Islam." ${ }^{\prime 1}$

In the last generation of the Enlightenment, that of revolutionary intellectuals like Maréchal, and more famously Charles Dupuis, the Ghebres became representatives of natural philosophy or the cult of Nature: "This estimable population is still practicing and realizing

39. This edition, also in four volumes, seems to be the rarest: there is a copy at the Bibliothèque municipale in Lyon (Réserve).

40. Maréchal, Costumes civils actuels de tous les peuples, vol. III, Notice historique sur la Perse, $1-11$.

41. Philippe Roger, “Tolérance et 'minorité' à l'âge des Lumières ," Études littéraires 32, 1-2 (2000), 161-73: 171. Also see, for an example, Pierre Briant, "Montesquieu et ses sources: Alexandre, l'Empire perse, les Guèbres et l'irrigation," Studies on Voltaire and the Eighteenth Century 6 (2007), 243-62. 
today the principles of Natural Philosophy in whose theory we are instead so conversant," wrote Maréchal in the Costumes civils. ${ }^{42}$ In 1800, he would list the Ghebres in his Dictionnaire des athées, this time quoting Dupuis' Origine de tous les cultes (1794) as support. ${ }^{43}$

A more original example of Maréchal's effort is offered by the pages on the small Nootka population, the Nuu-chah-nulth, met by Captain Cook on the Western coast of Canada in 1778. The Nootkas, Maréchal said, kept statues in their homes, but they did not consider them sacred, like the Penates in Roman homes. Proof of this was the fact that they were ready to sell them: they knew they could easily make new statues, that is, they understood that the statues - and, by implicit extension, the gods themselves - were man-made simulacra. Their only cult was natural, obedience to family fathers, and this, in Maréchal's very patriarchal view, was true for almost all other semi-savage peoples. Using Captain Cook's account, Maréchal also gave a short dictionary of their most important words, underlining the fact that they had the words for the sun and the moon, that is, for a natural cult, but no religious terms. Of course he needed to say they were superstitious for the royal censor, who nonetheless erased some sentences here and there (replaced by very visible dots). The message, however, was clear enough.The way Maréchal ended his pages on the Nootkas synthetized his view: "On the other hand, it is distressing to think that despotism and superstition have sometimes been the sour fruits of Civilization!." ${ }^{\text {"4 }}$

Still, he did not actually idealize these faraway or insular peoples in his words, while the illustrations did idealize their looks. This is evident from a comparison with drawings by eye witnesses or based on direct testimonies: just as the ungainly Tierra del Fuegian woman depicted by Alexander Buchan was instead a half-naked beauty in Costumes civils, vol. IV, the cone-shaped headgear of a Nootka man

42. Maréchal, Notice historique sur la Perse, 2.

43. Charles Dupuis, Origine de tous les cultes, ou Religion universelle (Paris: Agasse, an III), t. I, 28 and 281. It should be noted that a new edition of the Voyages du chevalier de Chardin en Perse was published under Napoleon (Paris: Le Normant, 1811), edited by another member of the Institut, Louis Langlès. See also Jacques André Naigeon, Encyclopédie méthodique. Philosophie ancienne et moderne (Paris: Panckoucke, 1791-94), t. II (1792), 653-56, a reprint of Boulanger's Encyclopédie article "Guèbres."

44. Maréchal, Costumes civils actuels, t. IV, Moeurs et coutumes des habitans de Nootka, 13. The vocabulaire follows, 13-14. 
drawn by scenographer Philippe de Loutherbourg for the pantomime Omai (1785), based on eye witness portraits, was a hat worthy of a Parisian milliner on a Nootka woman in Costumes civils..$^{45}$ Maréchal, on the other hand, was only interested in using the descriptions of these peoples to show choices that he thought could still be open to civilized Europeans, as narrated in a recent book he cited, the now famous Lettres d'un cultivateur américain by Michel-Guillaume SaintJohn de Crèvecoeur. The author wrote about the first colonists of Connecticut: families living in loose association, without any form of coercive power.

Not much more than a year after Maréchal's inner, existential hope for change in a near future had reached its lowest point, during his spell in jail, discouraging him from attempts at total political transparency, the Revolution seemed to make those radical choices real and immediate. "What should one conclude from all our examples?" Maréchal asked in his 1790 pamphlet on civil religion, finally able to reveal more explicitly the idea underlying his choice of favorite populations in the Costumes civils:

What do some semi-savage hordes have in common with entire nations at the height of civilization? Honestly, can Quakers or Tschouwaches serve as models to Frenchmen? If their customs are not repugnant to reason or the nature of things, why not. ${ }^{46}$

Living according to nature, those populations were evidence that cult and power were historical products, not divine or anthropological givens. Maréchal believed that revolutionary France should shed organized religion and government completely and revert to small self-governing communities. That was the deepest meaning he attributed to one of the texts that most visibly and admittedly inspired his intellectual career ${ }^{47}$ - the last chapter of baron d'Holbach's Système de la nature (1770), the Abrégé du code de la nature, where Nature's

45. See these images in Terence C.Mitchell, ed., The British Museum Yearbook 3. Captain Cook and the South Pacific (London: British Museum Publications, 1979), 126 and 57. On idealization on classical lines, see Peggy Davis, "L'Antiquité retrouvée en Amérique: les images de l’Amérindien en Apollon du Belvédère," Lumen, 26 (2007), $143-58$.

46. [Sylvain Maréchal], Décret de l'Assemblée nationale portant règlement d'un culte sans prêtres, (Paris: n.p., 1790), 26.

47. See my Finalmente il popolo pensa, 61-64. 
passionate exhortation to her children resounds: Reviens donc, enfant transfuge; reviens à la nature! Return to the right path, my wandering child; return to nature!

He soon knew it was a chimerical hope. As he wrote at the beginning of 1793 in the Correctif à la revolution, in the context of the debates on the new republican Constitution: "The citizen should not resent the Sage's chimeras; let the latter dream as much as he likes! Or are even his dreams to be feared?."48

His politics remained radical all the way to the disastrous end of the Conspiracy of Equals in 1796. Afterwards, he would resort again to serial works like the above mentioned Voyages de Pythagore - an engagé variation on the enormously successful model of Barthélemy's Voyage du jeune Anacharsis - and, in 1800, the Histoire universelle en style lapidaire. Again, encounters with ancient and distant worlds. We could however say that now the veiling of the message was explicit: in different passages of these texts, double doctrine and hermetic communication were discussed.

Maréchal was not in financial need now. Instead, those genres seemed to be psychologically tied for him - as much before as after the Revolution - to a feeling of demoralization and at the same time a strategic and operative retreat into long-term intellectual and political resistance. In fact, they were effective and potentially lasting forms of communication with the readers' public, because they satisfied a real cultural demand: as we have seen, in 1799 Deterville was happy to publish Maréchal's new six-volume effort. The Italian translation of the entire Voyages de Pythagore in twelve volumes during the Risorgimento is also worth mentioning as an indication of effectiveness. ${ }^{49}$ There would however be no second political chance. When Maréchal died, under Napoleon's Consulate, in January 1803, preventive censorship was already re-established for the press and it would be formally extended to books again a few years later under the Empire.

48. Maréchal, Correctif à la révolution, LXXXV, 63.

49. Sylvain Maréchal, I viaggi di Pitagora in Egitto, nella Caldea, nell'India..., 12 vols. (Venezia: Andreola, 1827-28). 